\title{
Who Is the Ruler Here? Dispute between Danzig and Stephen Bathory on the Character of Power in the $16^{\text {th }}$-Century Commonwealth
}

1. "The fifth form of the Commonwealth [apart from monarchy, oligarchy, democracy and aristocracy] is what in our common language is called Commonwealth, and Polity by the Greeks. But because this form is rare, it has no own name, and there is no knowledge about it." Sebastian Petrycy's thought, interspersed into his translation of Aristotle's Politics, has not lost - despite the lapse of time - its timeliness and relevance. Neither at that time long ago nor today is it clear what the $16^{\text {th }}$-century Commonwealth was.

An interesting occasion to make some ascertainment was created by Bathory's war with Danzig (Gdańsk) waged in 1576-1577 and many a time described by historians. ${ }^{2}$ But this conflict, apart from a well-known military aspect, had also the character of propaganda clash, as was rightly pointed out over a hundred years ago by Kazimierz Morawski in his study devoted to Andrzej Patrycy Nidecki. ${ }^{3}$ Some other facts in this field have been established by Alodia Kawecka-Gryczowa and Konrad Zawadzki. ${ }^{4}$

1 Arystoteles, Polityki Arystotelesowej to jest rzadu Rzeczypospolitey ksiag ośmioro..., transl. by Sebastian Petrycy, Cracow, 1605, Book 4, Chapt. 7, p. 359.

2 K. Lepszy, Stefan Batory a Gdańsk. Rzut oka, Gdańsk, 1933 (published also in Rocznik Gdański, 6, 1932); P. Simson, Geschichte der Stadt Danzig, vol. 2, Danzig, 1918, passim. 3 K. Morawski, Andrzej Patrycy Nidecki, jego życie i dzieta, Cracow, 1892.

4 A. Kawecka-Gryczowa, 'Dzieje "Drukarni latającej”', Rocznik Biblioteki Narodowej, 7, 1971, pp. 355-76; K. Zawadzki, 'Akcja prasowa Stefana Batorego w czasie wypraw moskiewskich 1579-1581', in Dzieje polskiej kartografii wojskowej i myśli strategicznej. Materiaty z konferencji, ed. by B. Krassowski and J. Madej, Warsaw, 1982, pp. 119-25. 
But researchers of the Bathory era had focused largely on the king's wars against Muscovy. And no attempt has been made to interpret the content of published propaganda, with the main emphasis being put on its form, whereas ephemeral prints published during the war are the most interesting example of a polemic between the king and nobility and the townsmen. A thesis could be put forward that in the background of this controversy is a question about the nature of relationship between Danzig and the Commonwealth, examined within the context of the political system of the latter and the problem of the right of resistance.

The right to resistance is one of the most interesting problems related to political culture and philosophy. The article on the right of the nobility to renounce allegiance to the king was included into the Pacta Conventa, and thus it played the role of pillar of the legal system in the state. Most often, historians have been looking for its sources in Polish medieval political thought. ${ }^{5}$ In the face of lack of studies on reception of Western European political theories in the Commonwealth it is difficult to specify an alternative concept in historiography, which would indicate other sources of this thought; a question about the influence of the Monarchomachs was posed years ago by Czesław Chowaniec, but he did not leave the sphere of assumptions. ${ }^{6}$ The problem has recently been brought up by Henryk Gmiterek, who put forward a thesis that the popularity of the Reformed Evangelical Church - and not the Lutheran one - among noblemen was related to the lack of the right of resistance in the Lutheran doctrine: only Calvinism was able to provide sufficient arguments supporting the right to resist the magnate elite. But, in the light of the above reflections, it is impossible to agree to this hypothesis, which is based on a premise that the impact of the Reformation of the nobility was only superficial, and Protestant doctrines were used only as tools in their fight against magnates and had no influence on religious beliefs of noblemen. ${ }^{7}$ It is impossible to agree with these suppositions,

5 J. Szujski, 'Artykuł o wypowiedzeniu poshiszeństwa', in idem, Opowiadania i rozporządzenia historyczne, Warsaw, 1882, pp. 370-98; H. Litwin, 'W poszukiwaniu rodowodu demokracji szlacheckiej', in Między monarchą a demokracją. Studia z dziejów Polski XV-XVIII wieku, ed. by A. Sucheni-Grabowska and M. Żaryn, Warsaw, 1994, pp. 13-53.

6 C. Chowaniec, 'Poglądy polityczne rokoszan 1606-1607 wobec doktryny monarchomachów francuskich', Reformacja w Polsce, 3, 1924, pp. 256-66.

7 H. Gmiterek, 'Die Rezeption reformatorischer Ideen und religiöser Widerstandtheorien innerhalb der polnischen Eliten', in Ständefreiheit und Staatgestaltung in Osteuropa, ed. J. Balhcke and H.-J. Bömelburg, Leipzig, 1996, pp. 217-27. 
unsubstantiated by sources, and it is necessary to return ad fontes, trying to include research results into the comprehensive picture of political and legal system of the Commonwealth.

The present text, after presenting the source basis and a short description of rules of functioning of ephemeral prints issued during the Danzig war, places special focus on those elements of the argument which were directly related to the political system of the Commonwealth. Primarily, on the interpretation of social contract, understood both as a union of citizens constituting the state, and as a contract between the subjects and the monarch. A second issue is the place occupied by the city within the political system of the Commonwealth, and here an attempt was made to reveal the relationship between the image of the city and justification of the right of resistance. Finally, it is demonstrated how the "ignorance" Sebastian Petrycy was talking about became a political argument. For both sides referred to a differently constructed vision of the noble republic.

2. There have been circa 45 works found, which were written during the war or are directly related to it. These texts could be generally categorized into four groups: Danzig propagandistic writings aimed against the king; writings of the royal camp against the rebelling city; occasional poetry composed in relation to the war; and ephemeral prints of informational character. The texts belonging to the last two categories were, of course, anonymous, while it has proven to be possible to identify a majority of authors of the writings from the two first categories.

The anti-Danzig texts do not form a comprehensible whole. A part of them was written on commission and was playing a propagandistic role. Franciszek Mincer, however, published an account which is an example of anti-Danzig print which could not be regarded as Bathorian because of its mild criticism of the king's actions. ${ }^{8}$ On the other hand, one of these texts, which originated in Danzig and was published by the community in opposition to the city council, is clearly on the king's side?

8 Relacja o oblężeniu Gdańska przez Stefana Batorego w roku 1577', ed. by F. Mincer, Zapiski Historyczne, 30, 1965, 2, pp. 259-64; Cracow, Jagiellonian Library (hereafter, BJ), MS no. 107, p. 339.

9 Grundliche und warhajjtige Ursache, daß Patorischen Krieges vor Dantzig Anno 1677, [!]; Gdańsk, Library of the Polish Academy of Sciences, (hereafter, PAN Gd), NI $48^{\circ}$ adl. 5; handwritten copy: Grundlicher Belicht und Wahrhajflige Ursache des Bathorischen Krieges vor Dantzig, Anno 1577, Gdańsk, State Archive (hereafter, AP Gd), 300R/Vv 138, pp. 133-41. 
Bathorian propaganda was written mainly in Latin. It was in this language that the texts of Joachim Bielski (Satira in quendam Dantiscanum and Proteus), ${ }^{10}$ Andrzej Patrycy Niedecki (Commentarii de tumultu Gedanensi) ${ }^{11}$ and Jan Łasicki (Clades Dantiscana, published again under the title: Clades Dantiscanorum, and then translated into German by Leonard Thurneiser as Der Dantziger Niderlag $)^{12}$ were composed.

Among the printers, it was Melchior Nering who published the greatest number of these texts, including Łasicki's work and speeches addressed to the Danzigers. ${ }^{13}$ Surprisingly, he published more than Łapczyński, who printed only two works by Nidecki ${ }^{14}$.

The Danzig prints are written mainly in German and in their majority were issued for the first time either in Danzig or in Konigsberg, chiefly in Jakub Rhode's printing office. Their authors were generally anonymous. Some of the texts stand out above the rest, including: Declaratio vera quibus de causis ordines civitatis... (a contemporary German translation: Grundliche Erklerung aus was Ursache...) and an appendix to this print

10 I. Bielsci, Carmina latina, ed. by T. Bieńkowski, Warsaw, 1962, pp. 91-98.

11 Commentarii de Tumultu Gedanensi, Marienburg, 1577; PAN Gd Od 9 8, no. 7. 12 J. Łasicki, Clades Dantiscana MDLXXVII, Aprilis anno 1577, ed. by M. Neringk, Poznań, 1577; Warsaw, National Library (hereafter, BN), Mf 33696 (all my references are to this copy); Berlin, Staatsbibliothek Berlin Preußischer Kulturbesitz (hereafter, SBBPK), Sz5728 - it is among the war losses; Dresden, Sächsische Landesbibliothek Staats- und Universitätsbibliothek, Hist.urb.Germ. 452,6; idem, Clades Dantiscanorum anno 1577. 17 Aprilis, ed. by A. Wechelus, Frankfurt a/M, 1578; BN, Mf 33697 (all my references are to this copy); Munich, Universitätsbibliothek, 0001/8 Hist. 4575 (0001); Munich, Bayerische Staatsbibliothek, Polon. 51 m (3 copies); Cologne, Universität- und Stadtsbibliothek, Hauptabteilung: WAVI548; Stuttgart, Württembergische Landesbibliothek, HB 3404; Mannheim, Universitätsbibliothek, H 510 D 23 (9 an); Herne, Martin-Opitz-Bibliothek, C: 50; Trier, Universitätsbibliothek, 2an: Ae 79 8-o; Göttingen, Niedersäsische Staats- und Universitätsbibliothek, 8 H AM 1. 681: 4; Wolfenbüttel, Herzog August Bibliothek (hereafter, HAB), Alv.: Ik 192 (4) (2 copies); Leipzig, Universitätsbibliothek, Hist. Polon. 295 (2 copies); BJ, Cim 663, Cim 1481; idem, Der Dantziger Niderlag, Königsberg, 1579 (two twin editions): SBBPK, Rara, Flugschr. 1577, 3 (all my references are to this copy); Berlin, Geheimes Staatsarchiv - Preußischer Kulturbesitz, 21 b 129, 1577; PAN Gd, Od 9 8o; BJ, Cim Q 5343 (MSD); HAB H 419 (9) 4.

13 Oratio Leonhardi Gordecki, Posnaniae, Melchior Neringk a.D. 1577: Oratio Gedanensis secunda, Melchior Neringk, Poznań, 1578.

14 Cf. Drukarze dawnej Polski od XV do XVIII wieku, vol. 4, ed. by A. Kawecka-Gryczowa and K. Korotajowa, Wrocław, 1962, pp. 274, 378-87 ff. 
(Appendix, also translated as Anhang). ${ }^{15}$ Probably both were written with the thought of entering into negotiations with the king by the agency of the emperor and princes of the Reich in April and in the end of July and early August 1577.

Not going into complex problems of the language and techniques of propaganda, the analysed material allows us to put forward a thesis that in the case of all works it is possible to speak about propaganda through facts, for they referred to real events and documents. The choice of this strategy led occasionally to a paradox situation, when both sides of the conflict issued the same document - like in the case of Nidecki's text and part of the Grundliche Erklerung - hoping it would support their standpoint.

These works were addressed probably to princes and the emperor of the Reich, the nobility of the Commonwealth and the noblemen and princes of Western Pomerania. In numerous places the publishers of the Grundliche Erklerung turned to unparteischen Leuten, that is impartial people, uninvolved in the conflict. They probably had in mind witnesses of the conflict with the king, who were living in the territory of the Reich. ${ }^{16}$ A direct cause of this print was, as it could be supposed, a meeting of the princes and electors of the Reich planned on August of 1577 in Frankfurt on the Main. According to Paul Simson, in May of that year Johann von der Linde was released from prison in Mecklenburg and he established diplomatic contacts with the ruler of Denmark, then with the towns of the Hanseatic League. In July, on the other hand, the council sent Johann Boccacius to Emperor Rudolf II with their request that the

15 Declara- // tio vera quibus de // caussis Ordines Ciuitatis Gedanen- // sis cum Serenißimo Principe ac Domino Dn'o // Stephano Rege Poloniae etc. aduersa- // riorum suorum impulsu, iampriden in // eam, que nunc etiam durat, contro- // uersiam pertracti sunt. Pro innocentiae suae rationibus, \& // ipsius negocij circumstantijs palam demon- // strandis in lucem edita. Gedani Anno Diij M.D.LXXVII; [Rhode, 1577], PAN Gd, Od $24068^{\circ}$ : Appendix declarationis ordinum Civitatis Gedanensis de praesenti rerum statu mense Aprili nuper vulgatae, [no printing office], Gdańsk, 1577, [71] 11.; 18 cm; PAN Gd, Od $24068^{\circ}$; Anhang der Declaration der Ordnungen der Statt Danzigk, so unlangst im Aprill an den tag gegeben unnd in den Druck gefertiget, and Grundliche Erklerung // Aus was Ursache // die Ordnungen der Statt Dan- // tzigk / mit dem Durchlauchtigste Groß- // mechtigsten Fürsten und Herren / Herrn // Stephano Könige zu Polen ic. Durch // antrieb jrer Widdersacher / in den // jtzo noch obstehenden mitzuer- // standt und Weiterung gera- // ten und eingefüret, [no place and date]; [Rhode, 1577]; PAN Gd, 5m: Od $98^{\circ}$, Uph. Q 2370; Od $24078^{\circ}$, Od $24708^{\circ}$.

16 Grundliche Erklerung..., op. cit., ll. Vvij 1v, Vviij 2v. 
peace talks between the king and Danzig were held in Frankfurt before the Estates of the Reich. ${ }^{17}$ It was probably to the nobility of Pomerania that a text written in the Niederdeutsch dialect was addressed, ${ }^{18}$ for it was the dialect used in the principalities of Western Pomerania until the end of the $16^{\text {th }}$ century. ${ }^{19}$ Nota bene, the active participation of the Pomeranian nobility in the war on the side of Danzig - despite the objection of John Frederick and Duke Barnim X - is a well-known fact in the literature on the subject. ${ }^{20}$

The fact that Bathorian texts were printed mainly in Latin, and Danziger ones - in German, does not mean that they were addressed only to the elite. As it has been observed, some Danzig publications were issued with the thought of princes of the Reich and the emperor as their audience. On the other hand - a royal leaflet addressed to the townsmen gathered in front of the City Hall was written both in German and in Latin. ${ }^{21}$ Thus, we have reasons to believe that the Latin language was not the only distinguishing feature of social elites.

3. In the light of texts published by the both sides of the conflict, King Stephen Bathory and Danzig, a main moot point was the character of political system of the Commonwealth. The Danzigers were willing to emphasise its federalist aspect, according to which the state was a compact between equal political units directly subjected to the monarch. This made it necessary for the election to obtain consent from each member of the federation and was directly related to the oath sworn by King Stephen Bathory. The burghers, however, thought this was not a sufficient guarantee and protection, since their representatives were not present in Cracow during the ceremony of coronation and swearing in of the new king. The royal party, on the other hand, took the position of the

17 P. Simson, Geschichte der Stadt Danzig, vol. 2, Danzig, 1918, pp. 311-12.

18 J. Bolte, 'Ein Lied auf die Fehde Danzigs mit König Stephan von Polen', Altpreussische Monatsschrift, 1888, pp. 333-38; idem, 'Zum Liede auf die Danziger Fehde von 1576', Altpreussische Monatsschrift, 1891, pp. 636-39. On an ineffective search for these texts, see M. Toeppen, Volkstümliche Dichtung, Königsberg, 1872, p. 67.

19 O. Plantiko, Pommersche Reformationsgeschichte, Greifswald, 1922, p. 147; although in bigger towns Hochdeutsch began to be used more commonly, cf. H. Branig, Geschichte Pommerns, vol. 1, Cologne, 1997, p. 138.

20 Branig, op. cit., vol. 1, pp. 142-43; Z. Boras, Zwiąki Ślaska i Pomorza Zachodniego z Polska w XVI wieku, Poznań, 1981, passim.

21 Anhang..., op. cit., ll. Hiij 2r-1iij lr. 
superiority of the state over the united organisms. No part should be allowed to breakaway, and the oath sworn in Cracow was valid for all the state, that is for all its inhabitants, and it was not allowed to demand it to be renewed. It is worth taking a closer look at particular problems, beginning with an interpretation of the social contract, the question of opposition to power, and then going to the issue of the nature of the Polish state and the place of Danzig within this system.

3.1. The conflict between King Bathory and Danizg broke up in connection with a double election, of what both sides were fully aware and what was reflected in writings related with the war. The election of the king was associated with the conviction of the contractual nature of his rule, which is indicated by the composition of these texts - like Grundliche Erklemng or Anhang - which included a list of conditions between the king and the city. They present the conflict as preparations for the conclusion of the contract between the monarch and the city, and for this reason the Danzigers requested negotiations be conducted directly with the king. ${ }^{22}$ The dispute indicated also a bilateral character of obligations resulting from the contract: the king should cancel gravamina (grievances), and the ordynki (the representatives of all categories of townsmen) - should be obedient to the king. ${ }^{23}$ This way of thinking, however, led to an aporia resulting from the order of confirmation of privileges by the monarch and his recognition by his subjects: an unrecognised ruler could not meet demands of the subjects who had not recognised him and they did not want to subject themselves to the monarch who did not meet their expectations, that is - did not fulfil the contract. ${ }^{24}$

This raises the question about the nature of this controversy. It seems to have stemmed from a different interpretation of the theory of contract. The concept of contract present in the Danzig writings corresponds to the idea of the governmental contract (pactum subjectionis or Herrschaftsvertrag). ${ }^{25}$ And although this form is believed to be

22 Grundliche Erklemng..., op. cit., ll. Hhiij 1v-Ii 1r.

23 Ibid., l. Qqij 1v; cf. Anhang..., op. cit., l. R 1v; ibid., Hij $1 \mathrm{r}$.

24 Ibid., fol. N 1 r.

25 Cf. C. Porębski, Umowa spoteczna. Renesans idei, Cracow, 1999, pp. 9-14 (Bibliography, pp. 337-51); classic studies on the subject: J.W. Gough, The Social Contract. A Critical Study of its Development, Oxford, 1957: Social Contracts. Essays by Locke, Hume, and Rousseau, introduction by E. Barker, Oxford, 1971; A. Chmielewski, Spoteczeństwo otwarte czy wspólnota? Filozoficzne i moralne podstawy nowoczesnego liberalizmu oraz jego krytyka we wspótczesnej filozofi spotecznej, Wrocław, 2001, pp.140-46. 
characteristic of the medieval thought, we should refrain from hasty judgment of the Danzig political thought. To refer to the idea of pactum sociale (Gesellschaftsvertrag), that is to the social contract proper, was simply inconvenient for the Danzigers. This would mean that the city was recognised as part of the Commonwealth and in consequence - that the oath sworn by the king in Cracow applied also to Prussia and the Danzigers and that the representatives of the city were obliged to come to the Sejm sessions. And this was what the burghers wanted to distance themselves from, ${ }^{26}$ taking the position that they were in union with the king only. ${ }^{27}$ For this reason it was necessary after his death to re-establish the relationship with his successor on the throne. ${ }^{28}$ In the light of the governmental contract the Danzigers could request a re-negotiation of the contract after the death of the monarch. The question whether they could conclude it independently of the Commonwealth remains open. And although it would be logical to except that they had this right, the Danzigers - in the light of Grundliche Erklerung - persisted in the opinion that they had to abide by the joint decision made previously. Only in an exceptionally aggressive anti-Polish song entitled Der polnische Verstand an argument was used that in the face of the fact that the Danzigers supported the emperor, the Poles should accept the breakaway of the city: "Wy hebben vns ergeuen / dem romischen keiser twar, / jw wy uns nicht ergeuen, / dat ist gewißlich war." 29

The royal party did not publish a text which would resemble the Grundliche Erklerung, but in the light of the Danzig edition it is possible to attribute the concept of the social contract proper, that is Gesellschaftsvertrag, to the Bathorians. In this way we should understand the words of King Bathory's envoy Kossobudzki that the Danzigers were swearing the oath not to the king himself, but also to the Crown and the Polish Kingdom: "nicht allein dem Könige zu Polen geschworen, sondern auch der Cronen und dem Königreich Polen." ${ }^{30}$ An extremely important role in this concept - aside from the person of the king - was played by a community ("gemeinschafft der Cronen"), and for this reason avoiding the participation in the Sejm was considered reprehensible.

26 Cf. for example: Grundliche Erklerung..., op. cit., 1. Qqiij 1r.

27 Ibid., 1. Xxiij 2r.

28 Anhang..., op. cit., 1. Miij 2r.

29 Bolte, 'Ein Lied...', op. cit., p. 336; idem, 'Zum Liede..., op. cit., p. 638 (Wir haben uns ergeben dem Römischen Keiser zwar, ewrem wir uns nicht ergeben, das ist gewislich war). 30 Grundliche Erklerung..., op. cit., l. Cij 1v. 
Talking about the concept of power represented by the Bathorians, we should mention a surprising vision presented by Kossobudzki, which the Danzigers included in the Grundliche Erklerung. Kossobudzki said openly that the ruler was sent to the Commonwealth by God. ${ }^{31}$ For analytical purposes it is possible to distinguish three aspects of God's intervention. Firstly, Bathory had made a decision to be a candidate for the Polish throne under the inspiration of God, and because of his lust for power or a threat by enemies. ${ }^{32}$ The second proof of God's favour was the speed and swiftness with which he came to Cracow, since the distance between imperial Vienna and the capital of the Commonwealth was only 50 miles, while between Transylvania and Cracow - as much as 170 miles, ${ }^{33}$ beset with obstacles and dangers. ${ }^{34}$ And it was God that had made Maximilian to lose his zeal for rivalry. ${ }^{35}$ The third proof of God's interference was the situation in the country after Bathory had arrived - there was an immediate harmony between the quarrelling parties and all gathered around the newcomer from Transilvania, "as if driven in by a whip." 36 The nobility gave consent to the military draft, the archbishop recognised him as the king, and the Lithuanian and Prussian estates swore obedience and loyalty. ${ }^{37}$

God inspired Bathory's actions whose efficiency was the evidence of God's constant grace. God's Providence operated also within the Polish society, bringing people to concord and unity. Thus, the common election of the king was a sign of God's predestination. Practically, there was no distinction between the power created by the social concord and power given by God, since the concord is a manifestation of God's will. It is worth to notice the consequences of such an attitude: Kossobudzki declares that according to the king the Danzigers could have thought about the election of another king as long as Poland and Lithuania were divided. But from the moment when Bathory was crowned and took the throne, their separation from other estates became an offence against the oath, faith and honour. ${ }^{38}$

31 Ibid., ll. B 1v-Dij v.

32 Ibid., 1. B $1 \mathrm{v}$.

33 Ibid., 1. Biij 1v.

34 Grundliche Erklemng..., op. cit., 1. Biij 2v.

35 Ibid.

36 Ibid., 1. Biij 1v.

37 Ibid.

38 Ibid., 1. Ciij 1r. 
This emphasis put on the rule of unity gained deeper philosophical foundations in the published speech. Kossobudzki refers to Plato's views (philosophas Plato) and says that the best government combines the highest wisdom, justice and power ("die höchste weißheit, gerechtigkeit, und gewalt zusammen gefüget”). In this Platonic idealistic vision of reality the multitude is contrasted with unity, and the latter leads to peace which brings about prosperity and welfare - and Kossobudzki's argumentation proceeds along those lines. ${ }^{39}$

Kossobudzki's speech is the fullest example of belief expressed explicite about the divine origin of the royal power. But even here this idea was not expanded upon and it was not said that the ruler becomes the king in the moment of his anointment (although it was not by accident that emphasis was put on the archbishop taking the side of the king). It follows from the speech that Bathory was indicated by God and endowed with His grace even before the election. What seems very interesting in this context is the assessment of their own attitude made by the Danzigers: they thought that "they had the right to think about another ruler," until a consent was reached in the Commonwealth. ${ }^{40}$ And then, they added that from the perspective of the law, they could be forgiven. Thus, despite the articulated belief of the divine origin of the king's power, it was possible to maintain that he was vested with this power at the very moment of election. ${ }^{41}$

Some trace of the conviction that the act of anointing of the king means that God conferred power could be found in the work of Jan Łasicki. Despite the fact that the Protestant doctrine limited the number of Sacraments to two, the author says that the Danzigers guilt was that they did not want to accept or to kiss the hand of God's anointed ("nicht wollen küssen noch annemen gesalbten Gottes"; "nolle se unctum Dei osculari"). ${ }^{42}$ This is the more surprising that Łasicki could not be suspected of ignorance of the doctrine. Łasicki intentionally creates a Christocentric image of Bathory in order to emphasise the guilt of the Danzigers. Similarly, in Bielski's Proteus there is a sentence that the Gigantomachia sparked by the Danzigers is to raise hand against magnos Deos. ${ }^{43}$

39 Ibid., 1. C $1 \mathrm{r}$.

40 Ibid., ll. C lv; Ciij 2v.

41 Cf. ibid., 1. Aiij 2v.

42 Łasicki, Der Dantziger..., op. cit., 1. F 1v; Clades Dantiscana..., op. cit., 1. C 1v.

43 Bielski, Proteus..., op. cit., l. Aij 1v. 
Summing up this stage of reflections, it should be noted that although the two sides use the idea of contract, they underline its different elements: the Danzigers stress the moment of entering into the contract with the monarch, while the Bathorians - the pact between the members of the community. But as is evident from other comments published by the Danziger printer, this conviction of a contractual character of power was not in contradiction to the conviction of its divine provenance - which has been already pointed out by historians of political culture of the Polish nobility. ${ }^{44}$ What is striking, however, is such a small number of statements which would indicate Bathory as God's anointed. Apart from Łasicki, only Kossobudzki said so at the very beginning of his negotiations, and what is more - the Danzigers did not hesitated to publish this statement. It thus seems that the argument referring to the divine provenance of the royal power was not convincing for the expected audience of the published texts, which was evident for Bathory "press office". 45

3.2. Now, let us go to the second question, that is the political system of the Commonwealth and the place of the city within its structures. The Danzigers themselves often described their city as the "jewel" or "bulwark" of the Commonwealth. ${ }^{46}$ This definition of the location of the city involved the need to exercise special caution, for its possible difficulties would also hurt the Crown. ${ }^{47}$ The city as "vorburg und spitze, zu wasser und Lande" should remain at the side of the emperor both because of its own well-being and well-being of the Commonwealth, since the conflict with the ruler of the Reich could have exacerbated relations with other German states. It is worth to notice that in further negotiations, the royal side "stole" rhetorical means from the townsmen. The king's response, given to the envoys of the city after 26 June 1577 and very mild in tone, repeated the terms used by the Danzigers to describe their city: "an adornment of the state" (ein zier des Reiches) and its "bulwark and protection" (feste vorburgk und beschützung) - indicating that acting against the customs of the ancestors destroyed this state. It was also added that similarly to how difficult it would be to capture Lübeck against the will of the Reich, even more difficult was to capture Danzig against

44 U. Augustyniak, Wazowie i królowie rodacy, Warsaw, 1999.

45 Cf. W. Zakrzewski, Stefan Batory. Przeglad historyi jego panowania i program dalszych nad nią badań, Cracow, 1887, p. 9.

46 For example: Grundliche Erklerung..., op. cit., ll. Diij 1r; Liij 2r; Uiij 1v.

47 Cf. ibid., l. E 1 r. 
the will of the Crown. ${ }^{48}$ What is striking is that these words were given quite different meaning that they had had in earlier negotiations. The term "adornment" (zier) was used by the royal side as the synonym of liberties and privileges which the city had been granted by the kings. ${ }^{49}$

The Danzigers presented themselves also as a separate republic (particulare Rempublica), which was indicated by the following facts: they had their own councils, estates, treasurers and other officials, they used to have their own German chancellor (besondere Rethe, Stendere, Officianten Schatzmeister und andere [...], vorzeiten auch einen besondern Deutschen Cantzier), they had their separate laws, privileges, liberties and customs (gewonheiten), their own seal and rite of swearing the oath to the Crown (sonderlich Sigel und Eidesleistung an die Löbische Crone). ${ }^{50}$ Those liberties and customs created a value which had to be cultivated and handed over to the next generations ${ }^{51}$ - the Danzigers were only the intermediate between the ancestors and descendants, and the position of the city they compared to that of Lithuania. ${ }^{52}$ Such presentation of the role of Danzig was nothing new in the history of conflicts between the city and the Commonwealth or nothing unexpected. The city's burghers had resorted to those arguments when they protested against the executionist movement in their city and against the incorporation of Prussia into the Crown at the Lublin Sejm. ${ }^{53}$

Among many metaphors used to illustrate the position of the city one is especially striking, which termed the Danzigers as the children of Israel, the nation to whom their enemies afflicted terrible torment, but God did not let them fall..$^{54}$ It is important, because emphasis put on suffering and persecutions of the nation was related to the articulation in the 1560s of the doctrine of disobedience formulated in the circle of Dutch Calvinists. ${ }^{55}$ They share a popular belief, expressed in the chapter

48 Anhang..., op. cit., 1. Niij 2v.

49 Cf. Grundliche Erklerung..., op. cit., ll. Cij 1v; D 1r (Kossobudzki's speech).

50 Ibid., 1. K $1 \mathrm{r}$.

51 Ibid., 1. Q $1 \mathrm{r}$.

52 Ibid., 1. Iiij 2v.

53 A. Klonder, 'Prusacy na sejmie 1579-1580 - ostatnia próba przekreślenia Unii Lubelskiej', in Wtadza i spoteczeństwo w XVI i XVII w., ed. by M. Kamler, Warsaw, 1989, pp. 248-60.

54 Historia und Beschreibung..., op. cit., 1. Cij 1r.

55 M. van Gelderen, The Political Thought of the Dutch Revolt 1555-1590, Cambridge, 1992, pp. 64-109. 
13 of the Epistle of St. Paul to the Romans that there is no power - even the bad, cruel and tyrannical - but from God. ${ }^{56}$ Disobedience was allowed only when the ruler's orders were ungodly, but private persons could have resisted the king only when acting under God's inspiration as providential instruments. This brings up the problem of persecution as a sign of martyrdom. Many Calvinist authors regarded martyrdom as a sign of being chosen by God. This has been verified by the observations of Urszula Augustyniak who saw in the community of Lithuanian Calvinist their feeling of pride at sharing the "Evangelical alias Calvinist [faith] hold in contempt": persecution in the worldly life was regarded as a sign of predestination to the eternal life..$^{57}$ According to Martin van Gelderen, "the martyrologies showed that Reformer Protestant authors almost sanctified individuals who disobeyed the orders of worldly authorities to denounce their religion." 58 The Dutchmen referred to the motif of the "New children of Israel", creating the image of "patriotic martyrology." 59. "The conviction of being God's chosen nation was not [...] to guarantee good fortune and blessed prosperity." 60

Similar themes could be found in the writing Historia und Beschreibung. The author repeats threats hurled by the king: to hand men and women, and to kill infants in the wombs of their mothers. ${ }^{61}$ Since those threats were addressed against Christians, God would punish the enemy of the burghers for his bloodthirstiness, and he would fall by his own pride (Und also müssen erst sterben // Jrer hohmut halben verterben). ${ }^{62}$ This was even more clearly expressed in the Warhafftige und Grundliche Newe Zeytung by Berhard Meyer, who portrayed Bathory at the moment of his solemn oath that he would not withdraw until the city was raised to the ground, and that he would not spare even children in the wombs of their mothers. ${ }^{63}$ The royal troops operating in Prussia, responsible for - as

56 Ibid., p. 107.

57 U. Augustyniak, Dwór i klientela Krzysztofa Radziwitta, Warsaw, 2001, p. 26.

58 Gelderen, op. cit., p. 107.

59 After: A. Ziemba, Nowe dzieci Izraela, Warsaw, 2000, p. 118.

60 Ibid., p. 153 (the main thesis of Antoni Ziemba is that the concept of God's people was advocated not only by one party - the Predicants, as stated in the literature on the subject - but that it was willingly used by both sides - Orangists and anti-Orangists. A similar statement relating to Gdańsk parties is impossible in the light of the source material at hand).

61 Historia und Beschreibung..., op. cit., 1. Biij 1r.

62 Ibid., 1. Biij $1 \mathrm{r}$.

63 Newe Zeytung // Warhafftige und gründ- // liche Beschreibung..., op. cit., 1. Aij 2r. 
the author of Historia und Beschreibung painstakingly listed - murdering, plundering and burning, are described as "tyrannical horde" (Tyrannen schar). ${ }^{64}$ The city thus was forced to defend Christianity (Dardurch die Statt kommen zufall // mus sie Christum vor jrn Feldherm // Zum Schutz nehmen / und sich wehren). ${ }^{65}$ In other words, the city and Christian people were oppressed by tyrants, which forced Danzig to protect defenceless Christians, thus making the city an instrument of God's Provenance.

These arguments were related in the Historia und Beschreibung to other justification of the right to disobedience formulated by jurists from Saxony during the conflict with Charles V. They maintained that if the emperor wanted to impose his jurisdiction on the spiritual realm, he acted as an unjust judge, whose "violence was like that of any private person." Therefore it was justifiable to apply the doctrine formulated in Roman law to repel unjust force with force: vim vi repellere licere ${ }^{66}$. According to Philipp Melanchthon, it was "a natural instinct of self-preservation". ${ }^{67}$ Also the author of Historia und Beschreibung maintains that peace is the highest good but when it is impossible to live in peace, God permits to resort to war, and it is He who grants victory to those whose cause is just. ${ }^{68}$ According to another argument, natural law demands the protection of women and children. ${ }^{69}$

Similar reasoning, only a bit more developed, we find in the Grundliche Erklerung in its fragment commenting upon the events of 24 September 1576: faced with the extreme vileness and endangering of the citizens, it is in accordance with the natural, inherent right of all nations, the Danzigers have the right to resist violence and repay with the same coin (mit gleicher müntze wol einzubringen gelegenheit gehabt).$^{70}$ Despite this - as the Danzigers inform the readers - in order to prevent far-reaching consequences and prove their own innocence, they have no intention to resort to such drastic means. ${ }^{71}$

64 Historia und Beschreibung..., op. cit., 1. C 1r.

65 Ibid., 1. C $1 \mathrm{v}$.

66 Gelderen, op. cit., p. 63: the author quotes Digesta, Book 43, title 16, para. 1, sentence 27.

67 Ibid.

68 Historia und Beschreibung..., op. cit., 1. Cij $1 \mathrm{r}$.

69 Grundliche Erklerung..., op. cit., 1. Q 2v.

70 Ibid., 1. Oiij 1v.

71 Ibid., 1. Oiij 2r. 
We can assume, however, that these arguments were formulated in the Reich in the 1530s, and in the Netherlands in the 1560s. There was nothing unusual in the knowledge of the Danzigers about these polemics; but what I find more interesting is the fact that this argumentation was used as a commentary to writings presented to the broader audience. Yet, the most intriguing is the nature of the reasoning: the Danzigers assume that it is obvious for the audience that they can appeal to this right and they think they will rose in their esteem by resigning from their prerogatives.

As it has already been said above, while presenting their image, the Danzigers emphasised that they inherited their liberties from their forefathers and were responsible for passing them to their descendants. Seeing, on the one hand, that the king did not protect sufficiently their rights and privileges, and being aware, on the other hand, that the conflict could have dangerous consequences, the burghers found themselves according to their own words - in a tragic situation: they had to choose between the concern for their wives and children, which required peace, and their duty toward their ancestors and descendants, which required them to protect their freedoms and privileges. ${ }^{72}$ It seems to be a main argument when it comes to the disobedience to legitimate power.

An analysis of motifs associated with the right of resistance present in the polemic between Danzig and Bathory leads to apparently contradictory conclusions. First and foremost, the references to the right to resist seem to stem from German and Dutch polemics and they could be regarded as representative for certain interpretations of that right. Yet, although the problem was permanently present in the background of discussions, the references or allusions remain very sparse. This could have several reasons. Firstly, the conflict was too short to have produced theoretical treatises offering the legal and philosophical basis for both sides. An additional reason could have been the often changing course of war. Secondly, there was no audience for such texts, that is an educated republic. This, however, seems unlikely, since some of those texts were addressed to the citizens of the Reich, where such treatises were written and published, and they found their audience. And finally, thirdly, the Danizg council was not interested in "bringing forward heavy artillery" against the king, since it was obvious after Maximilian's death that both sides were condemned to reach an agreement. This explanation seems to be most probable.

72 Ibid., 1. Riij 1r (dated January 1577). 
3.3. Finally, let us turn to the image of the Commonwealth which emerges from the polemical texts compiled during the war. In his recently published article, Harald Kleinschmidt analysed two types of systems through the prism of which international relations were perceived. ${ }^{73}$ The first system is described as mechanistic one: all its elements are tied together in a fixed, static frame, and relations among states are to same extent self-regulating. ${ }^{74}$ The whole system reminds a machine with no space between its parts. The system represents well-ordered and hierarchically assembled units and cannot exist without them. These units are homogenous. This way of thinking about international relations was shared by - according to Kleinschmidt - Grotius, Hobbes or Pufendorf.

The biologistic international system is something more than only the sum of its parts which undergo dynamic changes. This thinking of the society was expressed by Aristotle's words: "In the order of time, the state is later than the family or the individual, but in the order of nature, prior to them; for the whole is prior to the part. As there could be no foot or hand without the body, so there could be no family or man, in the proper words of the sense, without the state." 75 Particular elements of the system are not homogenous, which means that if we regard the European system as the universe, it has as its elements both European states and other organisations and organisms. One of the central problems in the dispute about the right of resistance to authorities which took place at the turn of the 1520s and 1530s in the Reich was a three-stage relationship: the subject - the prince - the emperor. To present the Empire as the mechanistic system meant that it was made up of independent principalities headed by the princes bound by the authority of their office to protect and defend their subjects. Operating with biologistic categories led to a conclusion that any subject was subjected directly to the emperor, thus even the prince of the Empire had no right to resist the Emperor, even if in accordance with the rule: vim vi repellere licet, or - as Martin Luther said - "man muge gewalt mit gewalt steuren." ${ }^{\prime 6}$ Following this reasoning, still in March 1530

73 H. Kleinschmidt, 'Systeme und Ordnungen in der Geschichte der internationalen Beziehungen', Archiv für Kulturgeschichte, 82, 2000, 2, pp. 433-54.

74 Ibid., pp. 436-37.

75 Aristotle, The Politics, transl. into English by B. Jowett, Oxford, 1885, 1253a.

76 'Luther an Kurfürst Johann den Beständigen von Sachsen [Wittenberg, 6 March 1530]', in Das Widerstandsrecht als Problem der deutschen Protestanten 1523-1546, ed. by H. Scheible, Gütersloh, 1969, p. 61. 
Luther rejected the right of resistance, referring to the First Epistle of St. Peter the Apostle: "Honour all men. Love the brotherhood. Fear God. Honour the king." (2: 17).

It is possible to find in the Danzig publications traces of thinking about the state in the categories of mechanistic system. Above all, they presented the Commonwealth as a simple assembly of three elements: the Crown and two duchies: Lithuania and Prussia. ${ }^{77}$ The latter were described also as republics. Arguments were often directed towards one purpose: to demonstrate that Prussia was not part of the Crown, thus it polemicised with the provisions of the Union of Lublin. ${ }^{78}$ In consequence, a conviction that both the Danzigers and other citizens of Royal Prussia were not subject to the Sejm of the Commonwealth gained ground. ${ }^{79}$

The mechanistic system did not differ from the sum of elements it did not make a quality of its own - and for this reason it could be metaphorically said that it does not exist - but only its elements. In the same way the state "disappears" from the argumentation of the Danzigers, indicating that after the king's death they were not bound to the Commonwealth and they could demand a new contract. ${ }^{80}$

Contrary to this conception regarding the state as the assembly of units, the arguments used by the royal party maintained occasionally that the state was the creation of higher order - or of different type - than the elements making it. The state consisted of "two governments" (Regimenten): "The Crown and Lithuania", Prussia, on the other hand, was associated with Poland (mit Polen). ${ }^{81}$ The state was termed a Gemeinschaft, that is a community, with acquired some religious traits and was also called "communion der gantzen Cronen." 82 The desire to separate from it was called "perversum iudicum." ${ }^{33}$ The Danzigers, however, protested against this understanding of the community, maintaining that the term "gemeinschafft" did not imply the subjection and thus was quite different than "ruling" (für unsere Herren haben). ${ }^{84}$

77 Grundliche Erklerung..., op. cit., 1. liij 2v.

78 Cf. Klonder, op. cit., pp. 248-60.

79 Anhang..., op. cit., 1. D 2r.

80 Ibid., 1. Miij 2r.

81 Grundliche Erklerung..., op. cit., 1. Miij 2v (Polen in this fragment is identical with the Crown).

82 Anhang..., op. cit., 1. Iij 1v; Grundliche Erklerung..., op. cit., ll. Cij 1v; Tij 2v.

83 Grundliche Erklerung..., op. cit., 1. Eiij $1 \mathrm{r}$.

84 Anhang..., op. cit., 1. Miij 1r. 
The differences between the two ways of thinking were clearly evident in the discussion about the king's oath and rights in the Commonwealth. As it has been mentioned above, the Danzigers thought that the oath sworn by King Bathory in Cracow was not a sufficient guarantee of their privileges, because it guaranteed the preservation of the rights and privileges of the Crown and Lithuania, which were against the rights of Danzig: "quae iuribus utriusque, genitus Poloniae et Lithuaniae [...] sint contrariae." ${ }^{85}$ And - as they maintained - it was impossible for two opposite things to exist at the same time, which was exemplified by grievances and freedom mutually excluding. ${ }^{86}$ The royal side responded that the oath in Cracow did not confirm separately the laws and rights of each particular Land, but the general right of the whole Crown (das gemeine Recht der gantzen Cronen). And it was impossible for Prussian rights to be contrary to this right, since it was impossible that the state should exist whose laws (gesetze) would be against its rights (rechte). ${ }^{87}$ According to the mechanistic vision of the state, which is attributed to the Danzigers, there were no reasons for the existence of das gemeine Recht, and only the rights of the Crown, Lithuania and Prussia existed.

The both sides used the metaphor of the body and its members, often used in European political reflection. ${ }^{88}$ This figure of speech appeared already in Kossobudzki's speech, who declared that the king would use all means to bring the dismembered parts to the unity of the body. ${ }^{89}$ The same metaphor was used by the Danzigers in a different sense: taking care of well-being of the body means taking care of each its member, also "the smallest finger." 90 This unity constitutes the body - taking care of each of its members. ${ }^{91}$ Elaborating this thought, they maintained that Lithuania, Poland, Ruthenia and Prussia were members of the body: each of them had own rights and liberties and none of them should threaten another. ${ }^{92}$ "So ist es hinwiderumb auch

85 Grundliche Erklerung..., op. cit., 1. Iiij 2r; Anhang..., op. cit., 1. M 1v.

86 Grundliche Erklerung..., op. cit., 1. Fiij 2v.

87 Ibid., 1. Mij 2r.

88 This metaphor was very often used at least from Plato's times, cf. S. Grodziski,

Obywatelstwo w szlacheckiej Rzeczypospolitej, Cracow, 1963, pp. 56-60.

89 Grundliche Erklerung..., op. cit., 1. Bij 1r.

90 Ibid., 1. Kiij 1v.

91 Ibid., 1. E 1v.

92 Ibid., 1. Xxij 1v. 
nicht unbillig, eines jeden wolfart mit gemeinen zuthun in gebürender acht und mitsorge gehalten werde." 93

We should add that contrasting the biologistic system with the mechanistic one without the attributes of the time frames and applying it to the international relations seems to be very close to the classic opposition between Gemeinschaft and Gesellschaft. ${ }^{94}$ It is derived sometimes from the strong conflict between the Sophists and Plato, close to the conflict of $18^{\text {th }}$-century liberalism (John Locke) with traditionalism and of modern liberalism (John Rawls) with communitarianism. ${ }^{95}$ It would exceed the scope of the present study, however, to expand on these reflections.

4. Above, the discussion has been presented which took place in 1576-1577 between the king and the nobility supporting him on the one side, and the burghers from Danzig on the other. Besides many topics which were omitted during the preparations for the article, the polemic brought up the problems of political system of the Commonwealth and relationship between the city and the state. An important role in this conflict was played by the doctrine of the right of resistance to power which was in the background of the debate, and the question of origin of the royal power. And although both sides agreed in the latter question and maintained that the king's power came from the contract, it did not exclude the conviction of its divine nature. To defend themselves against an accusation of rebellion, they had to seek in other moral duties, for example toward their descendants, thus refuting a charge of being concerned for their own private advantage.

At the same time it turned out that the Danzigers used a different interpretation of the state than the royal party. The Commonwealth, according to them, was close to the federalist Reich and it may be possible to demonstrate that they used arguments of the towns of Western Pomeranian states, which in their conflicts with rulers appealed to the Supreme Court of the Reich (Reichskammergericht), maintaining that they were subordinate to the emperor and the jurisdiction of the Reich. When, after Bogusław X's death, the ducal throne was taken over by his sons George I and Barnim XI, a conflict erupted between the dukes and

93 Ibid., l. G 1v.

94 F. Tönnies, Wspólnota i stowarzyszenie. Rozprawa o komunizmie i socjalizmie jako empirycznych formach kultury, Warsaw, 1988.

95 Chmielewski, op. cit., p. 30. 
towns over the order of confirmation of privileges and paying homage. The conflict lasted for two years. ${ }^{96}$ Probably, it is possible to prove that the direct subjection to the ruler, as claimed by Danzig, was an attempt to gain a similar position to that of other towns of the Reich (Reichstädte), directly subordinated to the emperor.

All this indicates only that it is not easy to answer unambiguously the question what was the $16^{\text {th }}$-century Commonwealth. It certainly was not an anomaly, which has already been proven by Adam Manikowski and Andrzej Wyczański. The above-proposed attempt at interpretation of a public discussion proves, however, that also the contemporary people understood the nature of the $16^{\text {th }}$-century state in many different ways. In addition, the skilful selection of arguments and great ease in constructing them is the evidence of high political culture of both polemicising sides.

\section{Translated by Grażyna Waluga}

First published as: 'Kto tu rządzi? Spór między Gdańskiem a Stefanem Batorym o charakter władzy w szesnastowiecznej Rzeczypospolitej', Odrodzenie i Reformacja $w$ Polsce, 47, 2003, pp. 89-103.

96 M. Wehrmann, Geschichte von Pommern, vol. 1, Gotha, 1919, p. 22. 